\title{
Rental Building and Event Equipment Application at the Arcadia Function Hall Web-Based
}

\author{
Mulyati ${ }^{1}$, Ajay Supriadi ${ }^{2}$, Alim Imadudidn ${ }^{3}$ \\ ${ }^{1,2,3}$ Raharja University, JL. Jendral Sudirman No.40 Modern Cikokol Tangerang \\ e-mail: mulyati@raharia.info, ajay.supriadi@raharia.info, alim@raharia.info
}

\begin{abstract}
The Journal Website is one of the tools used as a means of information and communication that is able to get rid of all the limitations that exist in other information and communication tools. One of the limitations of communication and information tools is about distance, with websites we can find various information in various parts of the world. At Arcadia Function Hall the building leasing process is done manually, so that the time spent is ineffective and in the storage of rental data it becomes insecure because it is not stored in a good system. From the above problems the authors are interested in designing Web Based Applications to be able to help the building rental process performance become more effective and efficient and can store all rental data safely and can produce accurate and accurate reports.in conducting this study explaining the running of the system is analyzed using SWOT and the implementation using Unified Modeling Language (UML). This is the reason why the author analyzes the building leasing system at the Arcadia Function Hall can easily compile want to lease and make an accurate and fast rental report.
\end{abstract}

Keywords: Website, Storage, Information, Unified Modeling Language (UML).

\section{Introduction}

In Technology and Information are two things that cannot be separated at this time. This can be seen from the process of getting information that can be obtained quickly with the support of increasingly sophisticated technological advances [13]. This technological progress makes many people use web-based technology to help spread information because it is effective and efficient. With this progress, people can easily process the information so that the information becomes accurate and accurate [14].

Arcadia Function Hall is a building located in a housing that can be used for various types of events, one of which is a wedding. A system is needed that can improve the quality of service to the community, especially to people in residential areas who need a place for an event to be held [15].

The problem of data processing is one of the problems that are often faced by various types of companies and agencies, one of which is faced by building managers at the Arcadia Function Hall. In the management of ordering data for building leases, it is still manual or using books so that it causes a lot of problems [16].

Based on these problems, the authors are interested in taking the title "APPLICATION OF BUILDING RENTAL AND EVENTS IN WEB-BASED ARCADIA FUNCTION HALL".

\section{Research Method}

In carrying out the design on a system there are several important things that must be considered, including the existence of research methods to solve various formulation of the 
problems that exist in this research stage. In writing this journal using the 4 stages used in the research method are as follows:

1. Observation

2. Literature Review

3. Analysis

4. Implementation

\section{A. Observation}

According to Rahardja, $\mathrm{U}$ et al in the Technomedia Journal (2018). "Observation method is a data collection technique, where researchers make observations directly on the object of research to see closely the activities and problems that are occurring that are being carried out and as a problem solving. Observation methods can also be interpreted as observing and recording systematically the symptoms seen in the research subjects [1].

\section{B. Literature Review}

Definition of literature review according to Ariawan and Sri Wahyuni in the Global Sisfotek Journal (2015: 62), "Literature study is to study theories and find information relating to problems in accordance with the title of this research". The literature review is also called literature review, or literature review. Literature reviews help researchers to see ideas, opinions, and criticisms about the topic that were previously developed and analyzed by scientists. The importance of a literature review to look at and analyze the added value of this research is compared with previous studies [2].

Literature studies were carried out as one of the application of research methods. The following is the research that has been conducted and has a correlation with the research that will be discussed in writing, including:

1) Research conducted by Andreas Prasetya from STIKOM AKAKOM in 2016 entitled "Web Based Car Rental Information System in Satrio Langit G-zOne In Satrio Langit G-Zone Web Based Car Rental Information System" system used on Satrio Langit G zOne has not been optimally computerized as data input is still done manually, for that an information system is needed through the internet that can facilitate rental transactions so that it is more effective and efficient [3].

2) Research conducted by Ryan Kusuma Ramadhan from Andalas University in 2018 entitled "Design and Development Booking Online Wisma Rental and Hall Building PT. Indonesian Railroad Regional II Division West Sumatra Based on Web and Mobile "The rental system used there is only done by contacting the employee's telephone or coming directly to the location. From the problems that there are authors, the author made an Online Booking Application for House Rental and Hall Building PT. Kereta Api Indonesia with the aim to facilitate the provider in managing their business and analyze it based on the responses given by the customer [4].

3) Research conducted by Yudha Juniardi et al entitled "Designing Information Systems for Leasing the Web-Based Kopasus Command Center Building". Rental procedures that are applied there are still done manually and there are obstacles in registering where there are duplicate orders in the same time and place. For this reason, we need a system that can handle these problems by helping consumers see information [5].

4) Research conducted by Aditya Akbar Nugraha and Sugiono entitled "Information Systems for Leasing Indoor Brebes Sports Buildings" system in making reports there is still relatively slow and difficult to obtain information about the condition and facilities of the building. Based on the problem, the author designed a building rental information system that is able to provide accurate, effective and efficient information, as well as the performance of the management of the Leebes Indoor Sports Building [6]. 
5) Research conducted by Ulya Wahyu Hidayah entitled "Multipurpose Building Rental Portal Information System in Kudus-based Regency of Kudus" there is a lack of good management in terms of services such as recording rental data still carried out in notebooks and reports. Building information is still delivered among customers verbally. With the problems that exist there the author makes a system that can help customers inside [7].

The results of the literature review demonstrate a solid foundation and strong reasons for developing a system of information on inventory data of goods to be more effective and efficient.

\section{Analysis}

According to Sugiyono (2015: 334) "Analysis is difficult work, requires hard work. There is no particular way that can be followed to conduct an analysis, so that each researcher must look for a method that is felt to be suitable for the nature of his research. The same material can be classified differently " [8].

In this information system analysis method, the author uses the SWOT method, namely to evaluate strengths (strengths), weaknesses (weaknesses), opportunities (opportunities), and threats (threats) into a strategy in optimizing a more profitable business.

1. According to According to Ciarmiello, A. in international journals "SWOT Analysis and Stakeholder Engagement for Comparative Evaluation of Hybrid Molecular Imaging Modalities" (2016: 271-282), SWOT Analysis is a decision support tool designed to combine internal (strengths and weaknesses) and external (opportunities and threats) factors in planning organizational or technological change [9].

2. (According to Fredi Rangkuti in Nisak (2015: 3) SWOT analysis is to identify various types of factors systematically in order to formulate an organization's strategy. SWOT analysis is targeted at a logic that maximizes strengths and opportunities, but can simultaneously minimize weaknesses and threats. In making decision-making strategies that are used are always related to the development of a series of mission, goals, strategies and organizational policies. So, planning a strategy must be analyzed by the company's strategy factors (strengths, weaknesses, opportunities and threats) in the conditions that are happening [10].

3. According to Mulyati, et al in the journal ICIT Vol. 04 No. 02 (2018: 118), SWOT (Strenghts Weaknesses - Opportunities - Treats) is a strategic planning method that is used to evaluate the strengths, weaknesses, opportunities, and threats of a project [11]. So a SWOT analysis is a strategic planning method used to evaluate the strengths, weaknesses, opportunities, and threats in a project or business speculation.

\section{Implementation}

According to Fauzan Masykur (2014: 184) in his journal "Implementation That is implementing a design or design by writing program code according to the chosen programming language" [12].

In this research system planning will be carried out to be applied to the process of archiving incoming letters and outgoing letters to the Office of Tourism and Culture using the PHP programming language and the Unified Modeling Language (UML).

\section{Results and Analysis}

\subsection{Current System Analysis}




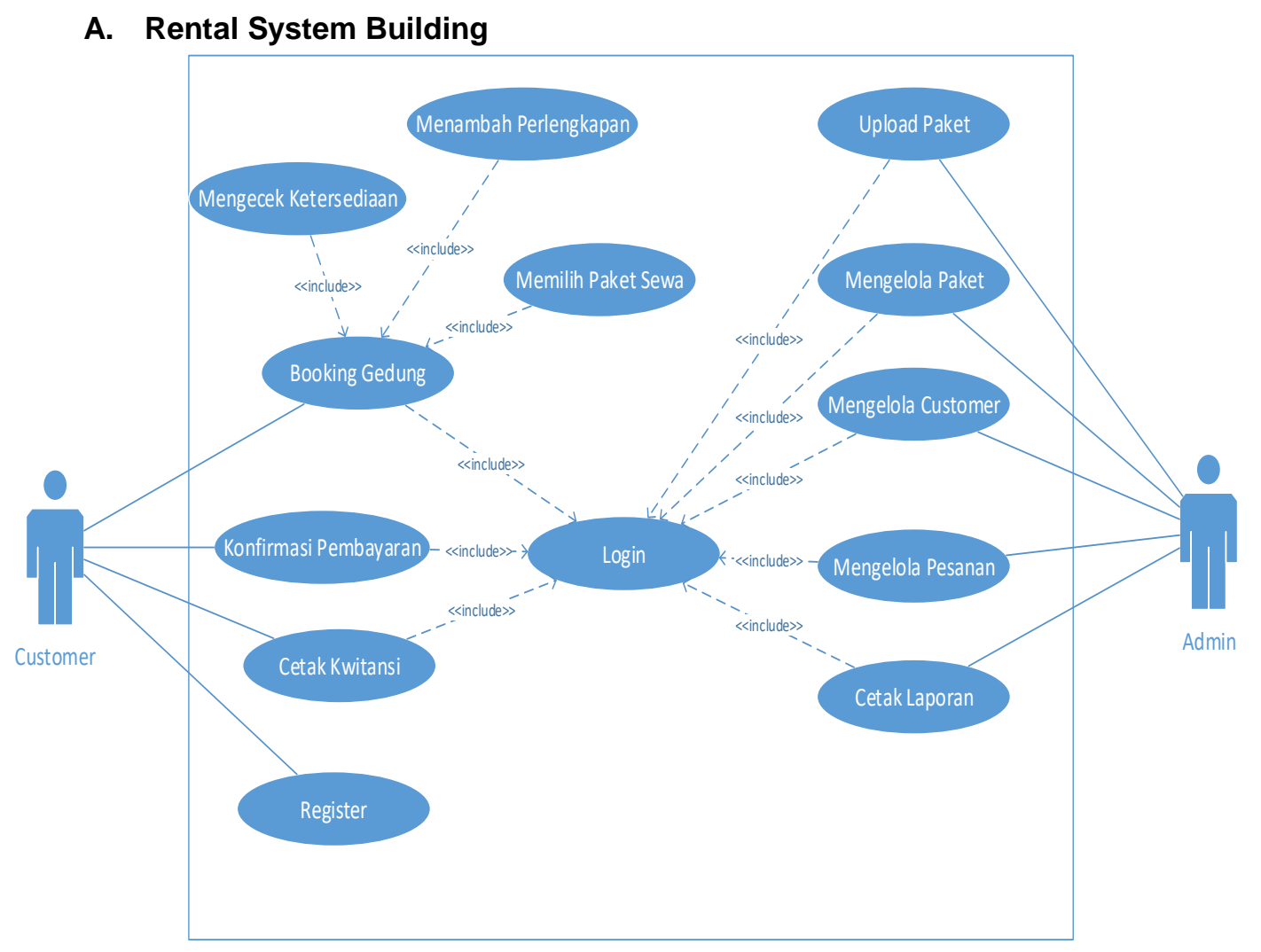

Figure 1. RentalSystem diagram

Based on the image 2. Use Case Diagram that runs at this time, there are:

a. 1 (one) system that covers all activities of the Rental Building and Event Equipment Application at the Arcadia Function Hall web-based

b. 2 (two) actors who carry out activities, namely: customer and admin

c. 13 (thirdteen) use case diagrams commonly carried out by these actors

\subsection{Proposed Program Design}

A. Display of Registration Page

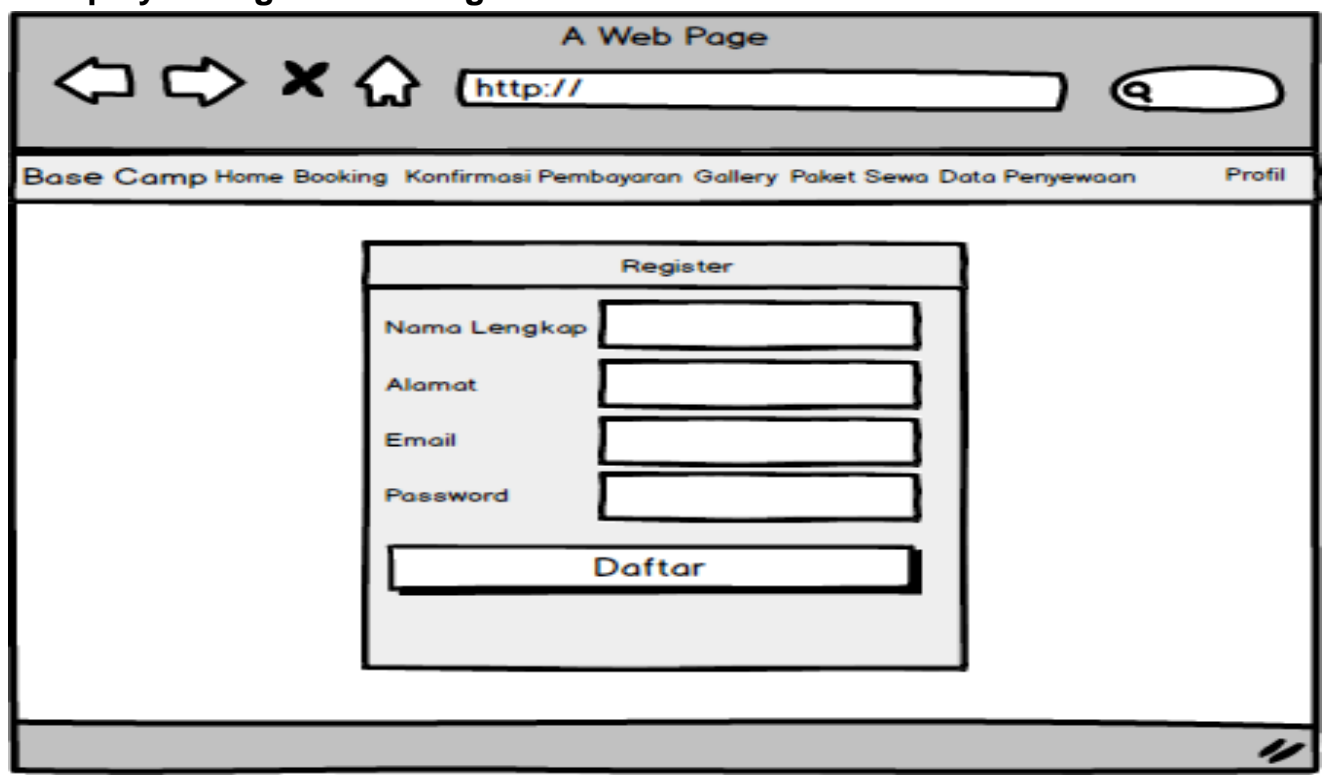


Figure 2. Display of Registration Page

B. Display of the login page Customer

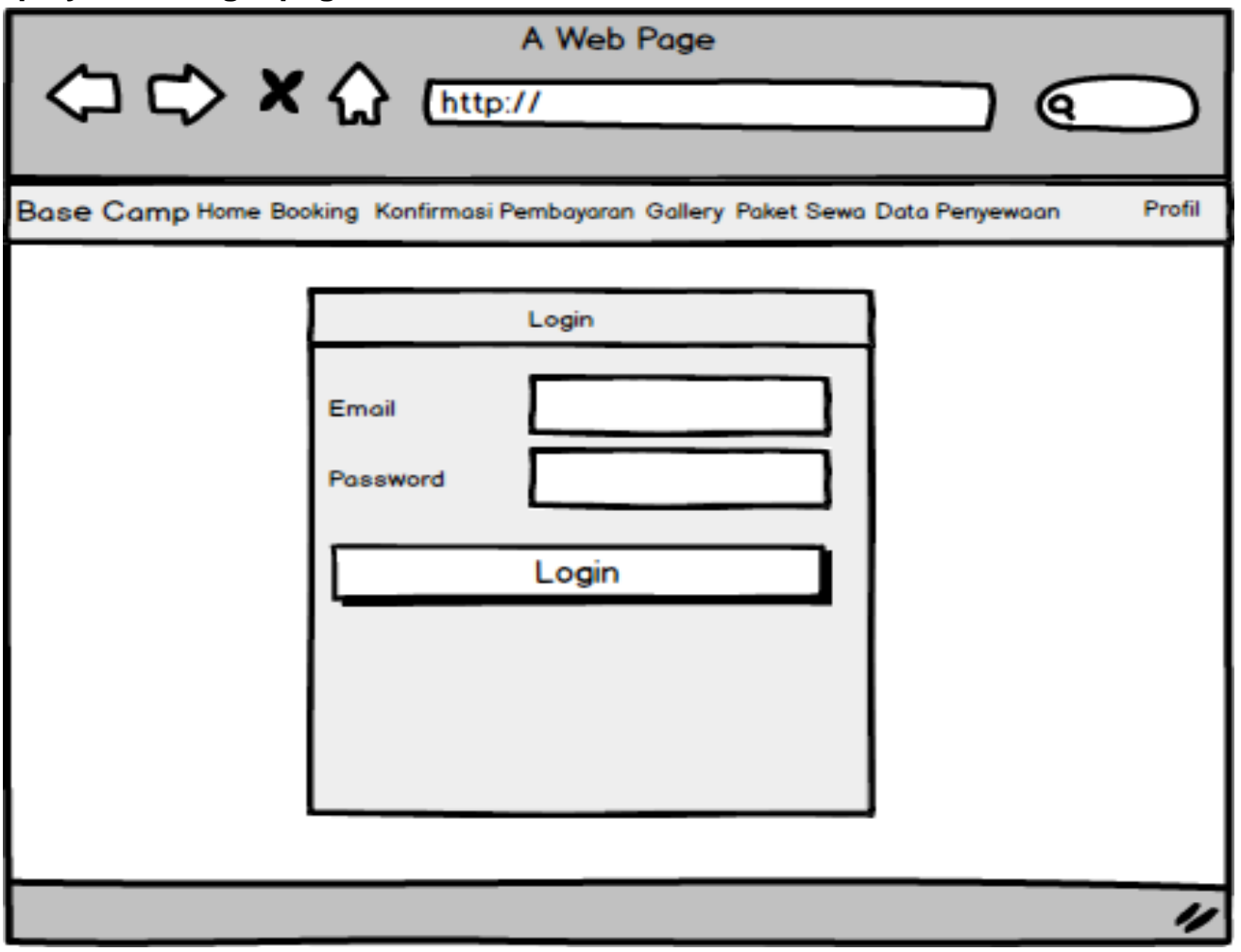

Figure 4. Display of the login page customer

C. Display of main menu and booking sistem

\begin{tabular}{c} 
A Web Page \\
\hline Base Camp Home Booking Konfirmasi Pembayoran Gollery Poket Sewo Doto Penyewoan Profil \\
\hline Pilih Tanggal Acaro \\
\hline Pilih Tanggal Ketersedioan \\
Cari
\end{tabular}


Figure 5. Display of main menu and booking sistem

D. Display of form personal data

Pemesanan untuk tanggal 2017-06-30

Nama Lengkap :

kuple

Alamat :

jakarta selatan

Nomor Telepon:

0998997878

Untuk acara :

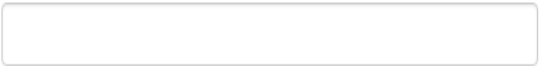

Waktu penggunaan :

Figure 6. Display of form personal data

D. Display of payment confirmation

Pemesanan untuk tanggal 2017-06-30

Nama Lengkap :

kuple

Alamat :

jakarta selatan

Nomor Telepon :

0998997878

Untuk acara : 
Figure 7. Display of payment confirmation

\section{F. Report Page Display}

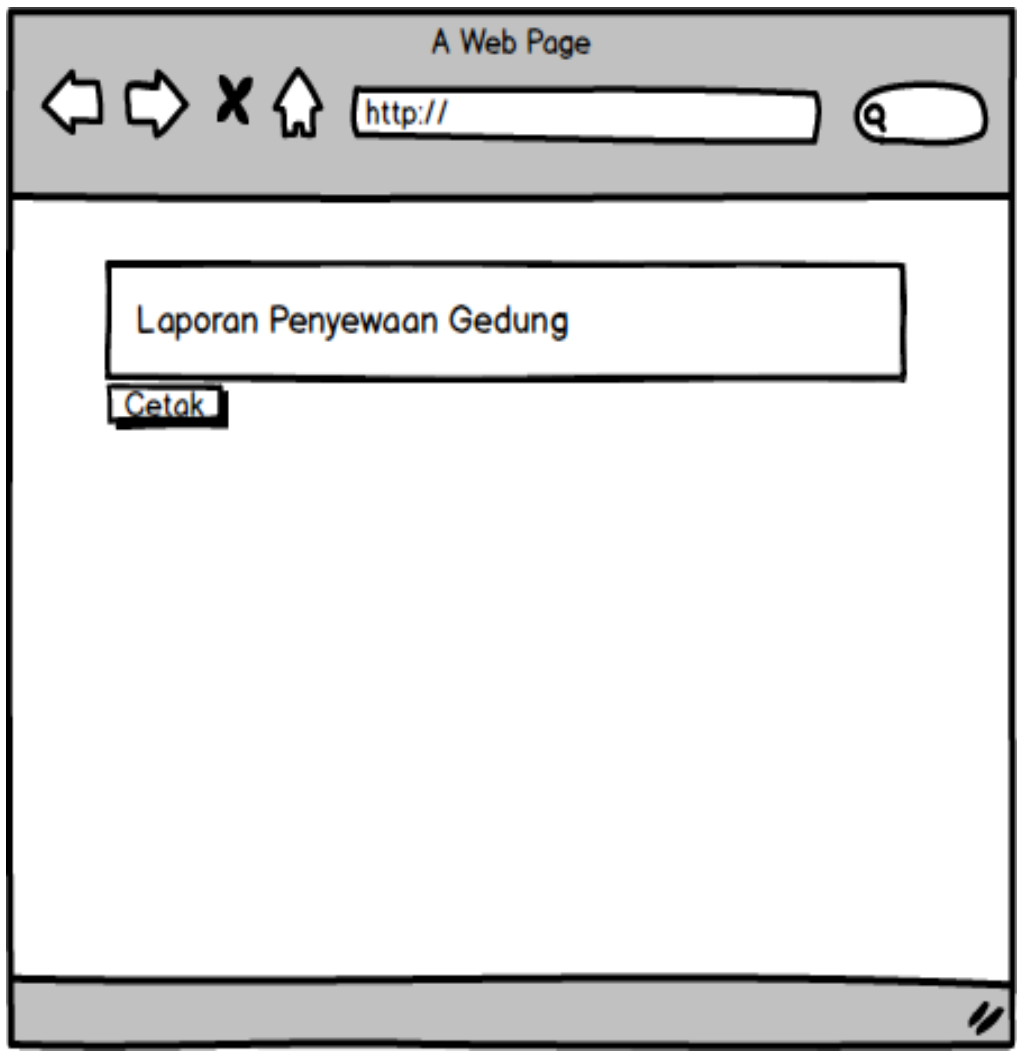

Figure 8. Report Page Display

\section{Conclusion}

Based on the explanations described in the previous chapters, there are conclusions about the application of building rental and event equipment at the web-based Arcadia Function Hall that can be concluded from the analysis and design. Through the application implemented with the PHP programming language with features produced include: building rental, addition of event equipment, payment confirmation, print payment receipts, print building rental reports. For data storage and reports, it can be stored properly in building rental applications and event equipment at this web-based Arcadia Function Hall. With this application, the use of time used to process building rentals can be done effectively and efficiently without wasting time in vain. This application can facilitate customers who use to add equipment if you want to add equipment to rent a building. This application can save all registered customer reports and building leases that have been done by the customer.

\section{References}

[1] Rahardja, U., et al. Utilization of Mailchimp as a Trend of Distribution of Payment Information for Students in Higher Education. Technomedia Journal (TMJ) Vol.2 No.2 Edition February 2018 E-ISSN: 2528 - 6544P - ISSN: 2620 -3383.

[2] Ariawan, Jesa and Wahyuni, Sri. 2015. Web-based Overtime Submission Application. GLOBAL SISPHOTECH JOURNAL Vol. 5 No. 1.

[3] Prastya, Andreas. 2016. "WEB-BASED CAR RENTAL INFORMATION SYSTEMS IN SATRIO LANGIT G-ZONE, STMIK AKAKOM Yogyakarta. September 19, 2016 
[4] Ramadan, Ryan Kusuma. 2018. "Application for Online Booking of Rental Houses and Building Hall of PT Kereta Api Indonesia Regional Division II West Sumatra Based on Web and Mobile. Andalas University. March 27, 2018

[5] Juniardi, Yudha et al. 2018. "DESIGN OF BUILDING RENT INFORMATION SYSTEM IN WEB-BASED KOPASSUS BALAI KOMANDO BUILDING". Informatics Journal of Computer Science Vol. 1 No.1 - April 2018

[6] Nugraha, Aditya Akbar and Sugiono. 2017. "BREBES DISTRICT INDOOR SPORTS RENTAL INFORMATION SYSTEM". Junral Komputer AMIK YMI Tegal, Vol.1 No.1 48-60. March 2017. ISSN 2548-5768

[7] Ulya, Wahyu Hidayah. 2018. "Information System for Multifunction Building Rental Portal in Kudus Regency Based on Web". Holy Mary University. August 23, 2018

[8] Nisak Zuhrotun. 2015. SWOT analysis to determine competitive strategies. EKBIS Journal. East Java: Lamongan Islamic University.

[9] Sugiyono (2015). Combination Research Methods (Mix Methods). Bandung: Alfabeta.

[10] Mulyati. et al. 2018. Web-based Time Attendance Information System at the Tangerang City Regional Disaster Management Agency. CCIT Journal. Tangerang: Raharja College. Vol.4 No.2 - August 2018. ISSN: 2356-5195.

[11] Masykur, Fauzan. 2014. "Implementation of Geographic Information System Using Google Maps Fire in Student Origin Mapping". Ponorogo: Muhammadiyah University Ponorogo. SIMETRIS Journal, (Vol. 5 No. 2 November 2014 ISSN: 2252-4983

[12] Ciarmiello, Andrea, Luciano Hinna. 2016. "Italy SWOT Analysis and Stakeholder Engagement for Comparative Evaluation of Hybrid Molecular Imaging Modalities". International Journal of Springer International Publishing Switzerland, Department of Nuclear Medicine, Second University of Naples, Department of Nuclear Medicine. Department of Nuclear Medicine, S. Andrea Hospital, La Spezia, Italy, Volume, 271282, ISSN: 978-3-319-31612-3.

[13] Rahardja, U., Lutfiani, N., \& Yolandari, A. (2019). Penerapan Viewboard Informatif Pada Asosiasi Perguruan Tinggi Swasta Indonesia Dalam Era Industri 4.0. Technomedia Journal, 3(2), 224-234. 